\title{
СПИСОК УСЛОВНЫХ СОКРАЩЕНИЙ
}

\begin{tabular}{|c|c|}
\hline ABY & - Археологічні відкриття в Україні \\
\hline АДУ & - Археологічні дослідження в Україні \\
\hline АИК & - Археологические исследования в Крыму \\
\hline АИУ & - Археологические исследования в Украине \\
\hline АЛЛУ & - Археологічний літопис Лівобережної України, Полтава \\
\hline АЛЮР & - Археологическая летопись южной России \\
\hline $\mathrm{AO}$ & - Археологические открытия \\
\hline АП УРСР & - Археологічні пам’ятки УРСР \\
\hline АСГЭ & - Археологический сборник Государственного Эрмитажа \\
\hline ВАП & - Вопросы археологии Поволжья \\
\hline ВДИ & - Вестник древней истории \\
\hline BCCA & - Вопросы скифо-сарматской археологии \\
\hline BXY & - Вестник Харьковского университета \\
\hline ГИМ & - Государственный исторический музей \\
\hline ДАС & - Донецкий археологический сборник \\
\hline ДГС & - Древности Геродотовой Скифии \\
\hline ДП & - Древности Приднепровья \\
\hline ДС & - Древности скифов \\
\hline ЗООИД & - Записки Одесского общества истории и древностей \\
\hline ИА РАН & - Институт археологии Российской Академии наук \\
\hline ИАДК & - История и археология древнего Крыма \\
\hline ИАИ & - Известия на археологическия институт \\
\hline ИАК & - Известия Археологической комиссии \\
\hline ИИМК РАН & $\begin{array}{l}\text { - Институт истории материальной культуры Российской Академии } \\
\text { наук }\end{array}$ \\
\hline ИРАИМК & - Известия Российской академии истории материальной культуры \\
\hline IA НАНУ & - Інститут археології НАН України \\
\hline КГИАМЗ & - Краснодарский историко-культурный музей-заповедник \\
\hline KIM & - Київський історичний музей \\
\hline КСИА АН СССР & - Краткие сообщения Института археологии АН СССР \\
\hline КСИА АН УССР & - Краткие сообщения Института археологии АН УССР \\
\hline КСИИМК & - Краткие сообщения Института истории материальной культуры \\
\hline МАИЭК & - Материалы к истории, археологии и этнографии Крыма \\
\hline MAP & - Материалы по археологии России \\
\hline МИА & - Материалы и исследования по археологии \\
\hline МИАР & - Материалы и исследования по археологии России \\
\hline MЧ & - Музейні читання \\
\hline НА IA НАНУ & - Науковий архів Інституту археології НАН України \\
\hline НА ЦОДПА & $\begin{array}{l}\text { - Науковий архів Центру охорони та досліджень пам'яток археології } \\
\text { управління культури Полтавської облдержадміністрації }\end{array}$ \\
\hline HAB & - Нижневолжский археологический вестник \\
\hline HЗXТ & - Національний заповідник «Херсонес Таврійський» \\
\hline НМИДК & - Новочеркасский музей истории донского казачества \\
\hline
\end{tabular}


НМІУ $\quad$ - Національний музей історії України

НMPA $\quad$ - Национальный музей Республики Адыгея

OAK - Отчет археологической комиссии

ПАВ - Петербургский археологический вестник

ПАЗ - Полтавський археологічний збірник

ПГКСВП - Проблемы греческой колонизации Северо-Восточного Причерноморья

ПСА - Проблемы скифской археологии

ПССАСП - Проблемы скифо-сарматской археологии Северного Причерноморья

PA

- Российская археология

CA

- Советская археология

САИ

СГЭ

- Свод археологических источников

ССКИЕ

ССПК

$\mathrm{C} Э$

- Сборник Государственного Эрмитажа

- Скифо-сибирское культурно-историческое единство

- Старожитності Степового Причорномор'я і Криму

ТГЭ

- Советская этнография

ТОИПК

- Труды Государственного Эрмитажа

УТОПІК

- Труды отдела истории первобытной культуры

ХДУ

Хсб

- Українське товариство охорони пам'яток історії та культури

ЦОДПА

- Харківський державний університет

- Херсонесский сборник

- Центр охорони та досліджень пам'яток археології управління культури Полтавської облдержадміністрації

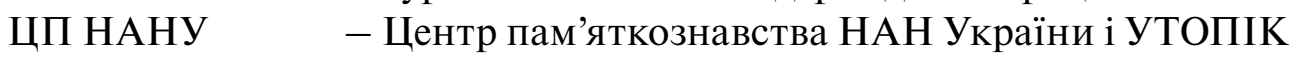

ЧIM

- Чернігівський історичний музей

ЧKM

BAR

- Чернівецький краєзнавчий музей

PBF

- British Archaeological Reports

- Prähistorische Bronzefunde 